\title{
Analisis Karakteristik Elektrik Limbah Kulit Singkong Berbentuk Pasta Sebagai Sumber Energi Listrik Alternatif Terbarukan
}

\author{
Tri Sutanto ${ }^{(1)^{*}}$, Amir Supriyanto ${ }^{(1)}, \&$ Arif Surtono $^{(1)}$ \\ ${ }^{(1)}$ Jurusan Fisika FMIPA Universitas Lampung \\ Jl.Prof. Dr. Soemantri Brojonegoro No.1 Gedung Meneng Bandar Lampung 35145 \\ *E-mail:tsutantovsungkal99@gmail.com
}

Diterima (1 Februari 2018), Direvisi (16 Februari 2018)

\begin{abstract}
The electrical characteristics of cassava peel and cassava can be determined by using a pair of electrode copper $(\mathrm{Cu})$ and zinc $(\mathrm{Zn})$. The measurement of the electrical characteristics of cassava peel had been done using a 5 watt LED load and when the load is released. Cassava peel and cassava are used without fermentation and with fermentation. Electrolyte cell that used consists of 20 cells, which were arranged in series and parallel, with volume $\pm 200 \mathrm{ml}$ for one cell. The maximum power generated cassava peel $5.8597 \mathrm{~mW}$, and $14.1052 \mathrm{~mW}$ on cassava. $\mathrm{Zn}_{2}$ electrode (zinc battery used) produces a larger power, which is $5.8597 \mathrm{~mW}$ compared with ZnI (ordinary zinc) is $1.9902 \mathrm{~mW}$. Cassava peel without fermentation produces a larger voltage of 20.76 volts, compared with cassava peel 19.17 volts of fermentation. In cassava peel, circuit cell power in series a larger of 5.8597 volts, compared with circuit power in parallel is 5.7078 volts.
\end{abstract}

Keywords :Cu-Zn electrode, Fermentation, Cassava peel.

\begin{abstract}
Abstrak. Karakteristik elektrik kulit singkong dan singkong dapat diketahui dengan menggunakan pasangan elektroda tembaga $(\mathrm{Cu})$ dan seng $(\mathrm{Zn})$. Pengukuran karakteristik elektrik kulit singkong dilakukan dengan menggunakan beban LED 5 watt dan saat beban dilepas. Kulit singkong dan singkong yang digunakan tanpa fermentasi dan dengan fermentasi. Sel elektrolit yang digunakan terdiri dari $20 \mathrm{sel}$, yang dirangkai secara seri dan paralel, dengan volume $\pm 200 \mathrm{ml}$ per sel. Daya maksimum yang dihasilkan kulit singkong $5.8597 \mathrm{~mW}$, dan $14.1052 \mathrm{~mW}$ pada singkongnya. Elektroda $\mathrm{Zn}_{2}$ (seng baterai bekas) menghasilkan daya yang lebih besar, yaitu $5.8597 \mathrm{~mW}$ dibandingkan dengan $\mathrm{Zn}_{1}$ (seng biasa) yaitu $1.9902 \mathrm{~mW}$. Kulit singkong tanpa fermentasi menghasilkan tegangan yang lebih besar yaitu 20.76 volt, dibandingkan dengan kulit singkong dengan fermentasi yaitu 19.17 volt. Pada kulit singkong, daya rangkaian sel secara seri lebih besar yaitu 5.8597 volt, dibandingkan daya rangkaian secara parallel yaitu 5.7078 volt.
\end{abstract}

Kata Kunci : Elektroda Cu-Zn, fermentasi, kulit singkong.

\section{PENDAHULUAN}

Listrik padam merupakan sebuah keadaan ketiadaan penyedian listrik di sebuah wilayah yang dampaknya luas. Penyebabnya dapat berupa perbaikan pada sistem pembangkit listrik, kerusakan di gardu listrik, kerusakan di jaringan kabel atau bagian lain dari sistem distribusi, sehingga terjadi pemadaman bergilir di Lampung. Saat ini, delapan pusat pembangkit listrik yang tersebar di Provinsi 
Lampung, yaitu PLTU Tarahan 2x100 MW, PLTU Sebalang 2x100 MW, PLTP Ulubelu 1 dan 2 masing-masing 2x55 MW, PLTA Besai 2x45 MW, PLTA Batutegi 2x45 MW, serta PLTD Tarahan 3 dan 4 masingmasing 2x100 MW, secara total menghasilkan sekitar 890 MW daya listrik. Dampak dari mati listrik dapat mengganggu aktivitas masyarakat, diantaranya tidak bisa nonton televisi, aktivitas perkantoran terganggu, tidak adanya sumber cahaya pada malam hari, perlu sumber listrik untuk charger baterai laptop, handphone, dan sebagainya. Sehingga, diperlukan sumber energy listrik untuk memenuhi kebutuhan saat listrik padam, yaitu bisa dengan memanfaatkan sumber daya alam yang tersedia. Salah satu umber daya alam yang berpotensi sebagai sumber energi listrik adalah limbah kulit singkong.

Menurut Badan Pusat Statistik (BPS) pada tahun 2015 di Indonesia produksi singkong mencapai 21.790.956 ton, sedangkan untuk daerah Lampung pada tahun 2015 mencapai 7.384.099 ton, atau sekitar 1/3 kali produksi singkong nasional. Hal ini menunjukkan berlimpahnya singkong di Indonesia khususnya untuk daerah Lampung [1]. Singkong telah digunakan oleh masyarakat umum untuk produksi tepung tapioka dan sebagai subtitusi makanan pokok, sedangkan daun singkong dikonsumsi sebagai sayuran. Kulit singkong yang merupakan bagian kulit luar umbi singkong tidak digunakan pada waktu penggunaan umbi, sebagian kecil kulit singkong ini hanya digunakan sebagai pakan ternak sedangkan sebagian lagi terbuang begitu saja. Setiap bobot singkong akan dihasilkan limbah kulit singkong sebesar 16\% dari bobot tersebut [2] berarti pada tahun 2015 di Indonesia sudah terdapat kurang lebih mencapai 3.486 .552 ton kulit singkong sedangkan untuk daerah Lampung kulit singkong yang dihasilkan mencapai 1.181.455 ton. Hal ini merupakan peluang besar untuk memanfaatkan limbah yang cukup melimpah tersebut[3].

Kulit singkong juga mengandung karbohidrat sebanyak 16,72 \%(Winarno, 1990), yang dapat membentuk asam asetat $\left(\mathrm{CH}_{3} \mathrm{COOH}\right)$, selain asam asetatterdapat juga asam sianida ( $\mathrm{HCN})$. HCN merupakan salah satu elektrolit yang dapat menghasilkan arus listrik, sehingga sangat memungkinkan bahwa kulit singkong dapat menghasilkan arus listrik. Untuk mengetahui karakteristik elektrik kulit singkong dan singkong dengan perlakuan menggunakan seng, berbentuk pasta, dan difermentasi untuk mengukur besarnya tegangan, hambatan dalam, dan arus yang dihasilkan [4]. Hasil dari penelitian ini dapat digunakan sebagai energi listrik alternatif terbarukan di Provinsi Lampung yang memiliki limbah kulit singkong sangat banyak.

Penelitian sumber energi listrik alternatif sebelumnya telah dilakukan oleh [5], yang menggunakan berbagai variasi bahan elekrtoda seperti tembaga $(\mathrm{Cu})$, alumunium $(\mathrm{Al})$, besi $(\mathrm{Fe})$, timah $(\mathrm{Pb})$, dan kuningan $(\mathrm{CuZn})$ untuk mengetahui efek kelistrikan yang ditimbulkan oleh variasi bahan elektroda yang terdapat pada limbah buah jeruk. Kemudian memanfaatkan baterai bekas dengan limbah kulit pisang dan durian sebagai sumber energi alternatif. Sedangkan, [6] melakukan analisis karakteristik elektrik limbah sayuran dengan memanfaatkan dua elektroda yaitu tembaga $(\mathrm{Cu})$ dan seng ( $\mathrm{Zn})$. Serta [7], melakukan analisis karakteristik elektrik menggunakan berbagai jenis kulit singkong dan singkongnya sehingga dapat dimanfaatkan untuk mengisi baterai handphone. Pada penelitian ini, telah dilakukan analisis karakteristik elektrik limbah kulit singkong dan daging singkong menggunakan tembaga, seng biasa, dan seng baterai bekas, dengan fermentasi dan tanpa fermentasi. 


\section{METODE PENELITIAN}

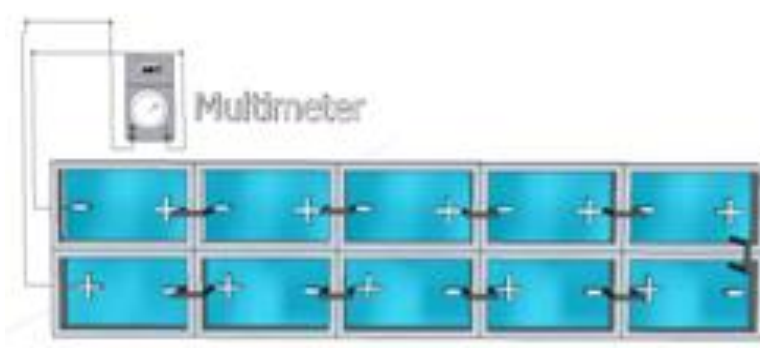

Gambar 1. Media tempat uji karakteristik elektrik.

Bahan yang digunakan dalam penelitian ini adalah kulit singkong dan singkongsebagai elektrolit, akrilik untuk membuat media tempat penampungan elektrolit, tembaga $(\mathrm{Cu})$, seng biasa $\left(\mathrm{Zn}_{1}\right)$, seng baterai bekas $\left(\mathrm{Zn}_{2}\right)$, perekat, kabel, jepit buaya, lampu LED 5 watt untuk menguji keberadaan karakteristik elektrik.

Peralatan yang digunakan dalam penelitian ini yaitu:multimeter, $\mathrm{pH}$ meter, gergaji besi, tang, gunting, gelas ukur,gunting, blender, dan spidol atau pensil. Pembuatan media tempat uji dibuat dari bahan akrilik yang dibentuk menjadi kotak persegi (sel) agar dapat digunakan untuk menampung berbagai elektrolit yang akan dibandingkan karakteristik elektriknya.

Data pengamatanakan di ambil setiap 2 jam sekali selama 24 jam, data yang diambil terdiri dari data pengamatan karakteristik elektrik limbah kulit singkong dan singkong saat beban dilepas $\left(\mathrm{V}_{\mathrm{bl}}\right)$, data pengamatan karakteristik elektrik saat menggunakan beban $\left(\mathrm{V}_{\mathrm{b}}\right)$, arus, kemudian data perhitungan untuk mencari daya $(\mathrm{P})$, dan hambatan dalam (Rin). Beban yang digunakan adalah rangkaian LED dengan beban 5 watt. Sedangkan media tempat uji karakteristik elektrik yang digunakan berbentuk kotak dengan ukuran panjang 10 $\mathrm{cm}$, lebar $6 \mathrm{~cm}$ dan tinggi $7 \mathrm{~cm}$, setiap sel akan dimasukkan pasta kulit singkong atau singkong $200 \mathrm{ml}$.
Gambar 2. menunjukkan desain media pengambilan data karakteristik elektrik, pengambilan data karakteristik elektrik limbah kulit singkong dan singkong tanpa fermentasi dan dengan fermentasi, menggunakan 20 sel yang tersusun secara 20 seri, 10 seri 2 paralel, dan 5 seri 4 paralel, dengan menggunakan elektroda tembaga $(\mathrm{Cu})$, seng biasa $\left(\mathrm{Zn}_{1}\right)$, seng baterai bekas $\left(\mathrm{Zn}_{2}\right)$.Sebelum akan melakukan pengambilan data karakteristik elektrik, juga akan mengambil data keasamaan dengan menggunakan $\mathrm{pH}$ meter.

\section{HASIL DAN PEMBAHASAN}

Telah dilakukan pengukuran karakteristik elektrik kulit singkong dengan menggunakan elektroda $\mathrm{Cu}$ (tembaga), $\mathrm{Zn}_{1}$ (seng biasa), dan $\mathrm{Zn}_{2}$ (seng dari baterai bekas). Jumlah sel yang digunakan untuk pengukuran sebanyak 20 sel, dengan 20 sel seri, 5 seri 4 paralel, serta 10 seri 2 paralel. Selain mengukur karakteristik elektrik kulit singkong, penelitian ini juga mengukur karakteristik elektrik singkongnya, serta mengukur karakteristik elektrik tanpa fermentasi dan dengan fermentasi. Selain itu, pengukuran karakteristik elektrik kulit singkong atau singkong dilakukan selama 1 hari atau 24 jam dengan rentang pengukuran setiap 2 jam sekali, dan pengukuran karakteristik elektrik kulit singkong atau singkong tanpa fermentasi, dan dengan fermentasi selama 3 hari.

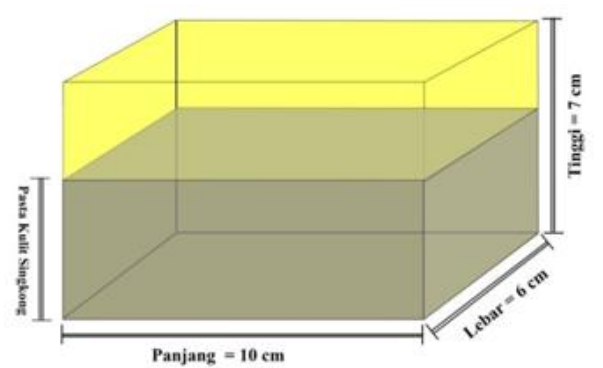

Gambar 2. Media tempat uji karakteristik elektrik. 


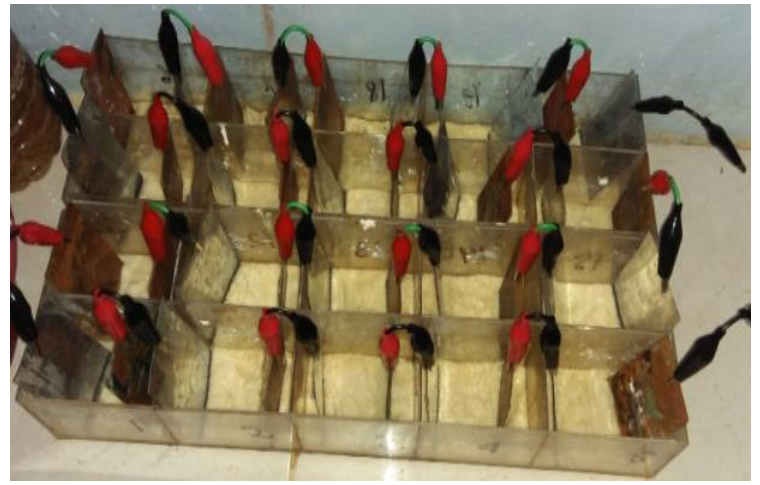

Gambar 3. Sel tempat uji karakteristik elektrik

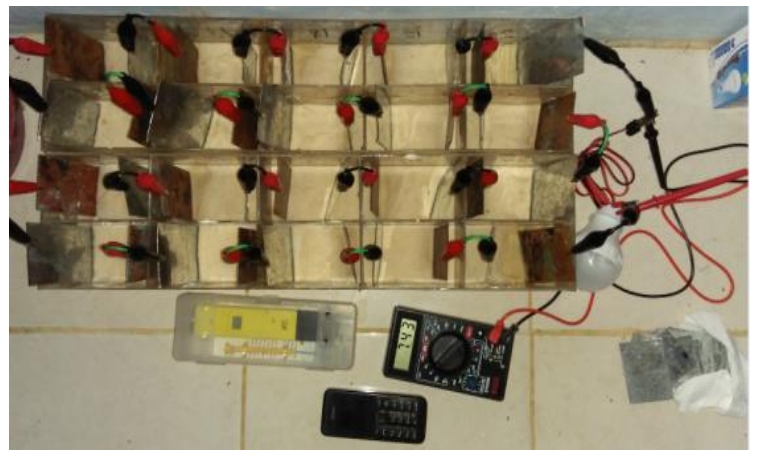

Gambar 4. Rangkaian keseluruhan sel tempat uji karakteristik

Pengukuran yang Selain itu, singkong atau singkong tanpa fermentasi, pengukuran karakteristik elektrik kulit dan dengan fermentasi selama 3 hari. singkong atau singkong dilakukan selama 1 Pengukuran yang dilakukan pada setiap hari atau 24 jam dengan rentang pengujian dilakukan sebanyak 5 kali pengukuran setiap 2 jam sekali, dan pengulangan.

pengukuran karakteristik elektrik kulit

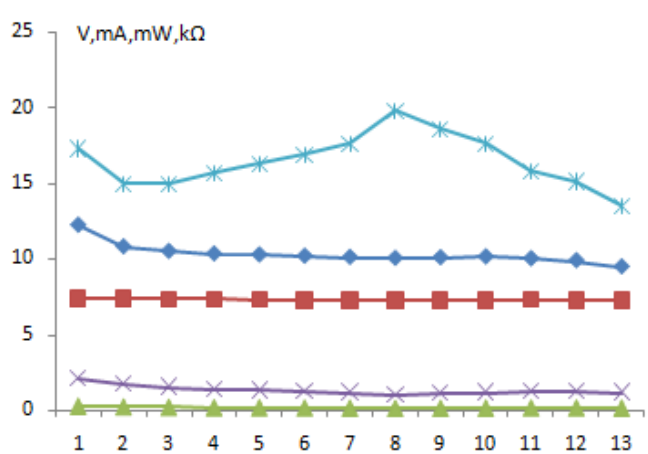

(a)

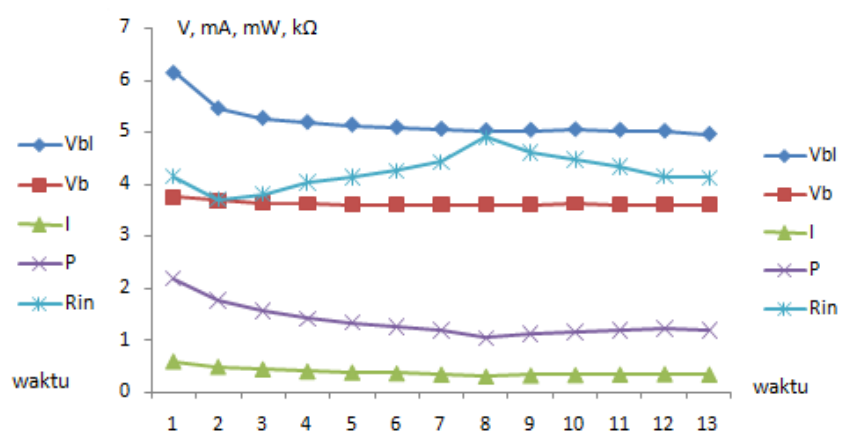

(b) 


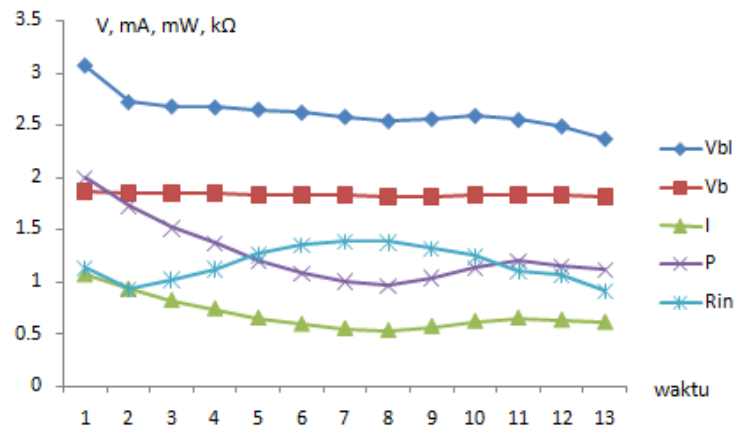

(c)

Gambar 5. Grafik hubungan karakteristrik elektrik kulit singkong tanpa fermentasi menggunakan elektroda $\mathrm{Cu}$ dan $\mathrm{Zn}_{1}$ terhadap waktu; (a) 20 seri, (b) 10 seri 2 paralel, dan (c) 5 seri 4 paralel.

Tabel 1. Kulit singkong dengan fermentasi 20 seri

\begin{tabular}{cccccccc}
\hline No & Pukul & $\begin{array}{c}\text { Waktu } \\
(\mathbf{J a m})\end{array}$ & $\begin{array}{c}\mathbf{V}_{\mathbf{b l}} \\
(\mathbf{V o l t})\end{array}$ & $\begin{array}{c}\mathbf{V}_{\mathbf{b}} \\
(\mathbf{V o l t})\end{array}$ & $\begin{array}{c}\mathbf{I} \\
(\mathbf{m A})\end{array}$ & $\begin{array}{c}\mathbf{P} \\
(\mathbf{m W})\end{array}$ & $\begin{array}{c}\mathbf{R}_{\text {in }} \\
(\mathbf{k} \mathbf{\Omega})\end{array}$ \\
\hline 1 & 12,00 & 0 & 10.9 & 7.5 & 0.62 & 4.65 & 5.483871 \\
2 & 14,00 & 2 & 10.53 & 7.46 & 0.51 & 3.8046 & 6.019608 \\
3 & 16,00 & 4 & 10.47 & 7.44 & 0.48 & 3.5712 & 6.3125 \\
4 & 18,00 & 6 & 10.34 & 7.41 & 0.44 & 3.2604 & 6.659091 \\
5 & 20,00 & 8 & 10.23 & 7.4 & 0.38 & 2.812 & 7.447368 \\
6 & 22,00 & 10 & 10.08 & 7.4 & 0.31 & 2.294 & 8.645161 \\
7 & 00,00 & 12 & 10.01 & 7.39 & 0.27 & 1.9953 & 9.703704 \\
8 & 02,00 & 14 & 9.89 & 7.38 & 0.23 & 1.6974 & 10.91304 \\
9 & 04,00 & 16 & 9.68 & 7.36 & 0.19 & 1.3984 & 12.21053 \\
10 & 06,00 & 18 & 9.44 & 7.35 & 0.21 & 1.5435 & 9.952381 \\
11 & 08,00 & 20 & 9.34 & 7.34 & 0.19 & 1.3946 & 10.52632 \\
12 & 10,00 & 22 & 9.21 & 7.33 & 0.18 & 1.3194 & 10.44444 \\
13 & 12,00 & 24 & 9.13 & 7.32 & 0.17 & 1.2444 & 10.64706 \\
\hline
\end{tabular}

Tabel 2. Singkong tanpa fermentasi 20 seri

\begin{tabular}{cccccccc}
\hline No & Pukul & $\begin{array}{c}\text { Waktu } \\
(\mathbf{J a m})\end{array}$ & $\begin{array}{c}\mathbf{V}_{\mathbf{b l}} \\
(\mathbf{V o l t})\end{array}$ & $\begin{array}{c}\mathbf{V}_{\mathbf{b}} \\
(\mathbf{V o l t})\end{array}$ & $\begin{array}{c}\mathbf{I} \\
(\mathbf{m A})\end{array}$ & $\begin{array}{c}\mathbf{P} \\
(\mathbf{m W})\end{array}$ & $\begin{array}{c}\mathbf{R}_{\text {in }} \\
(\mathbf{k} \boldsymbol{\Omega})\end{array}$ \\
\hline 1 & 16,00 & 0 & 19.04 & 7.61 & 0.97 & 7.3817 & 11.78351 \\
2 & 18,00 & 2 & 15.92 & 7.54 & 0.69 & 5.2026 & 12.14493 \\
3 & 20,00 & 4 & 15.56 & 7.52 & 0.61 & 4.5872 & 13.18033 \\
4 & 22,00 & 6 & 15.1 & 7.51 & 0.58 & 4.3558 & 13.08621 \\
5 & 00,00 & 8 & 14.93 & 7.49 & 0.53 & 3.9697 & 14.03774 \\
6 & 02,00 & 10 & 14.6 & 7.49 & 0.5 & 3.745 & 14.22 \\
7 & 04,00 & 12 & 14.38 & 7.48 & 0.48 & 3.5904 & 14.375 \\
8 & 06,00 & 14 & 14.21 & 7.47 & 0.45 & 3.3615 & 14.97778 \\
9 & 08,00 & 16 & 14.08 & 7.47 & 0.42 & 3.1374 & 15.7381 \\
10 & 10,00 & 18 & 13.93 & 7.47 & 0.4 & 2.988 & 16.15 \\
11 & 12,00 & 20 & 13.79 & 7.46 & 0.37 & 2.7602 & 17.10811 \\
12 & 14,00 & 22 & 13.65 & 7.45 & 0.34 & 2.533 & 18.23529 \\
13 & 16,00 & 24 & 13.24 & 7.43 & 0.29 & 2.1547 & 20.03448 \\
\hline
\end{tabular}


Analisis Daya yang Dihasilkan Oleh Limbah Kulit Singkong dan Singkong

Singkong menghasilkan daya yang lebih besar yaitu $14.1052 \mathrm{~mW}$, dibandingkan dengan kulit singkong yaitu, $5.8597 \mathrm{~mW}$, karena bobot kulit singkong hanya $16 \%$ dari setiap bobot singkong. Daya yang dihasilkan pada kulit singkong 20 seri tanpa fermentasi sebesar $4,202 \mathrm{~mW}$, dengan fermentasi sebesar 5,8597 $\mathrm{mW}$. Pada 10 seri 2 paralel tanpa fermentasi sebesar 3,8122 $\mathrm{mW}$, dengan fermentasi sebesar $5,5713 \mathrm{~mW}$. Sedangkan pada 5 seri 4 paralel tanpa fermentasi sebesar 4,1638 $\mathrm{mW}$, dengan fermentasi sebesar 5,7078 $\mathrm{mW}$. Analisis elektrik pada limbah kulit singkong ditunjukan pada Tabel 3, sedangkan analisis pada singkong ditunjukan pada Tabel 4.

Tabel 3. Analisis kulit singkong

\begin{tabular}{|c|c|c|c|c|}
\hline No & Variabel & $\begin{array}{c}\text { Vb } \\
\text { (volt) }\end{array}$ & $\begin{array}{c}\mathbf{I} \\
(\mathbf{m A})\end{array}$ & $\begin{array}{c}\mathbf{P} \\
(\mathbf{m W})\end{array}$ \\
\hline 1 & $\bar{A}$ & 7.42 & 0.28 & 2.0776 \\
\hline 2 & B & 7.64 & 0.55 & 4.202 \\
\hline 3 & $\mathrm{C}$ & 3.75 & 0.58 & 2.175 \\
\hline 4 & $\mathrm{D}$ & 3.89 & 0.98 & 3.8122 \\
\hline 5 & $\mathrm{E}$ & 1.86 & 1.07 & 1.9902 \\
\hline 6 & $\mathrm{~F}$ & 1.91 & 2.18 & 4.1638 \\
\hline 7 & G & 7.5 & 0.62 & 4.65 \\
\hline 8 & $\mathrm{H}$ & 7.61 & 0.77 & 5.8597 \\
\hline 9 & I & 3.77 & 1.18 & 4.4486 \\
\hline 10 & $\mathrm{~J}$ & 3.79 & 1.47 & 5.5713 \\
\hline 11 & $\mathrm{~K}$ & 1.88 & 2.43 & 4.5684 \\
\hline 12 & $\mathrm{~L}$ & 1.89 & 1.89 & 5.7078 \\
\hline
\end{tabular}

Tabel 4. Analisis singkong

\begin{tabular}{ccccc}
\hline & Variabel & $\begin{array}{c}\text { Vb } \\
\text { No }\end{array}$ & $\begin{array}{c}\mathbf{I} \\
(\mathbf{m A})\end{array}$ & $\begin{array}{c}\mathbf{P} \\
(\mathbf{m W})\end{array}$ \\
\hline 1 & $\mathrm{~A}$ & 7.61 & 0.97 & 7.3817 \\
2 & $\mathrm{~B}$ & 7.78 & 1.24 & 9.6472 \\
3 & $\mathrm{C}$ & 3.81 & 1.78 & 6.7818 \\
4 & $\mathrm{D}$ & 3.89 & 2.39 & 9.2971 \\
5 & $\mathrm{E}$ & 1.92 & 3.81 & 7.3152 \\
6 & $\mathrm{~F}$ & 1.95 & 4.87 & 9.4965 \\
7 & $\mathrm{G}$ & 7.48 & 0.84 & 6.2832 \\
8 & $\mathrm{H}$ & 7.81 & 1.8 & 14.058 \\
9 & $\mathrm{I}$ & 3.73 & 1.61 & 6.0053 \\
10 & $\mathrm{~J}$ & 3.91 & 3.56 & 13.9196 \\
11 & $\mathrm{~K}$ & 1.88 & 3.31 & 6.2228 \\
12 & $\mathrm{~L}$ & 1.97 & 7.16 & 14.1052 \\
\hline
\end{tabular}

Keterangan : A. Tanpa Fermentasi 20 Seri $\mathrm{Zn}_{1}$, B: Tanpa Fermentasi 20 Seri $\mathrm{Zn}_{2}$, C: Tanpa Fermentasi 10 Seri 2 Paralel $Z_{1}$, D: Tanpa Fermentasi 10 Seri 2 Paralel $\mathrm{Zn}_{2}$, E: Tanpa Fermentasi 5 Seri 4 Paralel $Z_{1}$, F: Tanpa Fermentasi 5 Seri 4 Paralel $\mathrm{Zn}_{2}$, G: Dengan Fermentasi 20 Seri $\mathrm{Zn}_{1}, \mathrm{H}$ : Dengan Fermentasi 20 Seri $\mathrm{Zn}_{2}$, I: Dengan Fermentasi 10 Seri 2 Paralel $\mathrm{Zn}_{1}$, J: Dengan Fermentasi 10 Seri 2 Paralel $\mathrm{Zn}_{2}$, K: Dengan Fermentasi 5 Seri 4 Paralel $\mathrm{Zn}_{1}$, L: Dengan Fermentasi 5 Seri 4 Paralel $Z_{2}$

Pada pengukuran tegangan kulit singkong yang terbesar yaitu 7.64 volt pada kulit singkong tanpa fermentasi 20 seri menggunakan elektroda $\mathrm{Zn}_{2}$ (seng baterai bekas). Pengukuran arus kulit singkong yang terbesar yaitu $2.43 \mathrm{~mA}$ pada kulit singkong dengan fermentasi 5 seri 4 paralel menggunakan elektroda $\mathrm{Zn}_{1}$ (seng biasa). Sedangkan, untuk pengukuran daya kulit singkong yang terbesar yaitu $5.8597 \mathrm{~mW}$ pada kulit singkong dengan fermentasi 20 seri menggunakan elektroda $Z_{2}$ (seng baterai bekas). Elektroda $\mathrm{Zn}_{2}$ (seng baterai bekas) menghasilkan daya yang lebih besar dibandingkan dengan $\mathrm{Zn}_{1}$ (seng biasa), karena kandungan $\mathrm{Zn}_{2}$ (seng baterai bekas) lebih murni. Pada kulit singkong, daya rangkaian sel secara seri lebih besar yaitu $5.8597 \mathrm{~mW}$, dibandingkan daya rangkaian secara paralel yaitu $5.7078 \mathrm{~mW}$.

Pada pengukuran tegangan singkong yang terbesar yaitu 7.81 volt pada kulit singkong dengan fermentasi 20 seri menggunakan elektroda $\mathrm{Zn}_{2}$ (seng baterai bekas). Untuk pengukuran arus singkong yang terbesar yaitu $7.16 \mathrm{~mA}$ pada kulit singkong dengan fermentasi 5 seri 4 paralel menggunakan elektroda $\mathrm{Zn}_{2}$ (seng baterai bekas). Sedangkan, untuk pengukuran daya singkong yang terbesar yaitu $14.1052 \mathrm{~mW}$ pada singkong dengan fermentasi 5 seri 4 paralel menggunakan elektroda $\mathrm{Zn}_{2}$ (seng baterai bekas). Elektroda $\mathrm{Zn}_{2}$ (seng baterai bekas) menghasilkan daya yang lebih besar, dibandingkan dengan $\mathrm{Zn}_{1}$ (seng biasa), 
karena kandungan $\mathrm{Zn}_{2}$ (seng baterai bekas) lebih murni.

\section{KESIMPULAN}

Elektroda $\mathrm{Zn}_{2}$ (seng baterai bekas) menghasilkan daya yang lebih besar yaitu $5.8597 \mathrm{~mW}$ pada kulit singkong dan $14.1052 \mathrm{~mW}$ pada singkong, dibandingkan dengan $\mathrm{Zn}_{1}$ (seng biasa) yaitu $1.9902 \mathrm{~mW}$ pada kulit singkong dan $6.0053 \mathrm{~mW}$ pada singkong, karena kandungan $\mathrm{Zn}_{2}$ (seng baterai bekas) lebih murni.Kulit singkong atau singkong tanpa fermentasi menghasilkan tegangan yang lebih besar yaitu 20.76 volt, dibandingkan dengan kulit singkong atau singkong dengan fermentasi yaitu 19.17 volt, karena kulit singkong atau singkong dengan fermentasi mengandung lebih banyak alkohol yang merupakan elektrolit lemah.Pada kulit singkong, daya rangkaian sel secara seri lebih besar yaitu 5.8597 volt, dibandingkan daya rangkaian secara paralel yaitu 5.7078 volt.

\section{UCAPAN TERIMAKASIH}

Penulis mengucapkan terimakasih kepada dosen pembimbing penelitian, Kepala Laboratorium Jurusan Fisika Universitas Lampung untuk fasilitas laboratorium.

\section{DAFTAR PUSTAKA}

[1] Abdal dan A. Irwan, Fadhilah, "Analisis Hubungan Konduktivitas Listrik dengan Total Dissolved Solid (TDS) dan Temperatur pada Beberapa Jenis Air," jurnal, vol. 5, no. 1, p. 86, 2016.

[2] C. Hidayat, Peluang Penggunaan Kulit Singkong Sebagai Pakan Unggas. 2009.

[3] H. Chinyelu, C. H. Amos, T., dan
Bamidele, M.W., Madukosiri, "The Effect of Processing on the Sodium, Potassium and Phosphorus Content of Six Locally Consumed Varieties of Manihot esculenta Grown in Bayelsa State," Pakistan J. Nutr., vol. 8, no. 10, pp. 1521-1525, 2009.

[4] F. Winarno, "Singkong dan Pengolahannya," Aksara Baru, 1990.

[5] E. . Landis, "Some of the Laws Concersing Voltaic Cells," $J$. Franklin Inst. State Pennsylvania, vol. CLXVIII, no. 6, pp. 399-420, 1989.

[6] A. . Imamah, "Efek Variasi Bahan Elektroda Serta Variasi Jarak Antar Elektroda Terhadap Kelistrikan Yang Dihasilkan oleh Limbah Buah Jeruk (Citrus sp.)," Skripsi, 2013.

[7] Harjono, "Analisis Karakteristik Elektrik Limbah Sayuran Sebagai Sumber Energi Listrik Terbarukan," Skripsi, 2016.

[8] Irsan, “Analisis Karakteristik Elektrik Limbah Kulit Singkong (Manihot esculenta Crantz) Sebagai Sumber Energi Listrik Alternatif Terbarukan Untuk Mengisi Baterai Handphone," Skripsi, 2016. 
Sutanto Dkk :Analisis Karakteristik Elektrik Limbah Kulit Singkong Berbentuk Pasta Sebagai Sumber Energi Listrik Alternatif Terbarukan 